\title{
NUTRITIONAL EFFECTS OF SOME POLLEN TYPES ON HYPOPHARYNGEAL AND ACID GLANDS IN HONEYBEE WORKERS (APIS MELLIFERA L.)
}

\author{
Hosafy, M. Eshbah ${ }^{1}$, Abdelsalam A. Mohamed ${ }^{1}$, Osama, A. A. Zedan ${ }^{2}$, Ahmed, T. H. Ghanem ${ }^{1,2^{*}}$ \\ ${ }^{1}$ Plant Protection Department, Faculty of Agriculture, Minia University. \\ ${ }^{2}$ Plant Protection Department, Faculty of Agriculture, El-Azhar University, (Assiut branch). \\ *Corresponding author: ahmadganem320@gmail.com ;Tel:+01033047872.
}

\section{Article information \\ Received: 1 April 2021 \\ Revised: 5 May 2021 \\ Accepted: 11 May 2021}

\section{Key words \\ Honeybee \\ Apis mellifera \\ Pollen \\ Chemical analysis \\ Consumption \\ Acid gland sacs \\ Hypopharyngeal glands.}

\begin{abstract}
Pollen had a wide range of effects on honey bee. Caged honey bee workers were used to determine the nutritional effects of four main types of pollen collected by honey bee colonies from the study area on the food consumption rates, the development of the hypopharyngeal gland (HPG) acini and acid gland (AG) sacs in honey bee workers. Additionally, chemical analysis of the selected pollen types was performed. Pollen diets were as follows: broad bean pollen, date palm pollen, clover pollen, maize pollen and mixture of the for mentioned types beside the control pollen diet. The highest mean consumption was observed between 4th and 6th of day aged bees in all diets (23.05 $\mathrm{mg} . / \mathrm{bee} / 3$ days). The highest quantity of food consumption was recorded in the 18 th day when the workers were fed on date palm pollen $(75.42 \mathrm{mg})$, while the lowest recorded $59.17 \mathrm{mg}$ from maize pollen treatment. The highest mean acinal surface area of HPG was $0.0451 \mathrm{~mm} 2$, which measured at 9 days-old of bees in all diets. While the workers fed on mixture pollen diet had the highest significant mean recorded the acinal surface area of HPG $0.0450 \mathrm{~mm} 2$ comparing of $0.0223 \mathrm{~mm} 2$ in control. The considering increment in average volume of acid gland sac with had been obtained at 18 days-old $(0.7276 \mathrm{~mm} 3)$ that resembles the highest significant degree, the greatest mean volume of AG sacs was observed when bees were fed on broad bean pollen $(0.6419 \mathrm{~mm} 3)$, while the lowest mean was $0.3643 \mathrm{~mm} 3$ in control.
\end{abstract}

\section{Introduction}

Honeybees have usual nutritional requirements of carbohydrates, proteins, fats, minerals, vitamins and water. Their chief food consists of pollen and nectar or honey. Nectar is the main source of carbohydrates and water, whereas pollen is the primary protein source, and also carbohydrates, lipids, vitamins and minerals [1]. So pollen is an indispensable food to honeybee colonies and is necessary for growth and development of young bees, larvae and reproduction [2]. Adult workers require $4 \mathrm{mg}$ of utilizable sugars [3] and consume $5 \mathrm{mg}$ pollen per day [4].

Recent research of pollen protein content showed that pollen grains may contain over $60 \%$ protein [1]. Whereas [5] stated that protein content is variable in collected pollen from different sources from 8 to $40 \%$. In Bulgaria it ranged from 11.5 to $27.4 \%$ in 50 pollen sources [6]. The optimum level of protein required for brood rearing in honeybee colony ranged between 23 to $30 \%$, which yields different nutritive values for bees [7]. Pollen protein content can be use as an indicator of nutritional value and quality [8]. The development and the survival of honeybee colonies are therefore intimately associated with the availability of those nectar and pollen sources [9]. Moreover, pollen digestion by bees may also vary among plant species. This is also supported by beekeepers who categorize malnutrition or starvation as one of the main causes of honey bee colonies loss in Upper Egypt [10]. So providing adequate pollen is essential to ensure the long-term survival of a colony and to maintain its productivity and produced brood rearing [11]. Thus, an inadequate of pollen or protein food source causes a decrease in brood rearing [12], it is also essential for the development of the hypopharyngeal glands of nursing bees [13]. In addition, pollen protein is critical for the development of honey bee muscles, glands and other tissues [14]. The hypopharyngeal glands in nurse worker bees around 6-8 daysold in special are of great important and interest due to their secretion of royal jelly [15]. So these glands are the backbone of the development of honeybee colony [16].

Royal jelly fed to the queen, larvae and drones for the optimal development of the HPG, newly emerged bees must feed on protein food [13] and [17]. It has been, reported that pollen consumption is positively correlated with hypopharyngeal development [18]. Thus, HPG growth and development can be consider as important criteria that can be used to evaluation the suitability of a normal pollen diet or protein supplement fed to young bees [19] and [20].

Bee venom is produced in the abdomen of worker bees from a mixture of acidic and basic secretions its synthesized by the venom glands associated with the sting apparatus of worker and queens, stored in the venom reservoir and injected through the sting apparatus during the stinging process [21]. Bee venom secretion increases during the first two weeks of the adult worker's life and reaches a maximum when the worker bee becomes involved in hive defense and foraging [22] and [23]. The acid gland in honey bee workers is a simple long structure split in two branches by its end, opening into an ovoid sac [24]. 
Over there many factors affecting acid gland including honey bee race, age of bees, and feeding supply. In addition, the diets identified as beneficial for the development of HPG (Asparagus sp., Castanea sp., and mixed pollen) resulted insignificantly larger AG sacs compared to the protein-free control [25].

Thus, the purpose of this study is to determine the nutritional effects of four main types of pollen collected by honey bee colonies in the study area during the active season according to their chemical analysis on the food consumption rates of honey bee workers. Effects of honey bee workers age and quality of selected pollen types on the development of the hypopharyngeal gland acini and acid gland sacs in honey bees.

\section{MATERIAL AND METHODS:}

The present work was conducted in a private apiary located at Tanda village, Mallawy district, Minia Governorate, and laboratory tests were done in the lab of in Faculty of Agriculture, Assiut University, during 2018-2019 season.

\section{Experimental honey bee:}

The hybrid Carniolan bees (Apis mellifera carnica) were used in the present study.

Pollen types were collected every 3 days by pollen traps $30 \%$ efficiency from January to September 2018. Pollen grains reference slides were prepared by collecting pollen grains directly from the opened flowers of the coincided flowering plants around the apiary and compared the morphology of each species of pollen grains with those of pollen pellets obtained from pollen trap using a light microscope provided with camera according to [26]. Pollen types were stored under freezing temperature $(-18 \mathrm{C})$ for chemical analysis procedure [27]. Four samples from the dominant pollen in trap were subjected for chemical analysis. The chemical analysis of pollen samples was performed at the central laboratory of the Faculty of Agriculture, Assiut University.

\section{Chemical analysis of the pollen}

1- Moisture: It was determined by drying pollen samples to constant weight in an air oven at $60^{\circ} \mathrm{C}$, then percentage of moisture content was estimated [29].

2- Crud Protein content: Crude protein content was determined, in duplicate, according to Domas methods [30]. Total nitrogen content was determined using an elemental analysis, Calibrated against standards. Pollen samples $(0.2 \mathrm{~g})$ were weighted into a combustion boat, and combusted at $950 \mathrm{C}$ to determine total crude protein, nitrogen values were multiplied by a conversion factor of 6.25 [31].

3- Carbohydrate content: It was calculated by difference of $\%$ total content of protein, moisture, crude fiber, ash and lipids out of $100 \%$ [29].

4- Total lipids: lipids content of the pollen samples were measured gravimetrically after extraction with petroleum ether through using a Soxhlet lipid extraction apparatus [29].

5- Ash content: It was measured through heating pollen samples in a muffle furnace at $600 \mathrm{C}$ until a uniform gray-white ash remained. The samples were then weighted for estimation the average percentage of the ash content [29].
6- Crud fiber: It was determined by following the standard procedures of [30]. The representative percentage of fiber was estimated.

Newly emerging honey bee workers ( $0-6$ h old) were obtained from a single colony were selected from among the apiary colonies in the present study during the period extended from October to January 2018-2019 season, the bees that appeared were randomly selected from brood combs and entered into the test cages.

\section{Experimental cages}

This study conducted in experimental cages using newly emerged honeybee workers, the experimental wooden cages of $15 \times 15 \times 5 \mathrm{~cm}$. dimensions with a glass side and other covered with black muslin, (each cage contains 100 workers) as in Figure 1 .

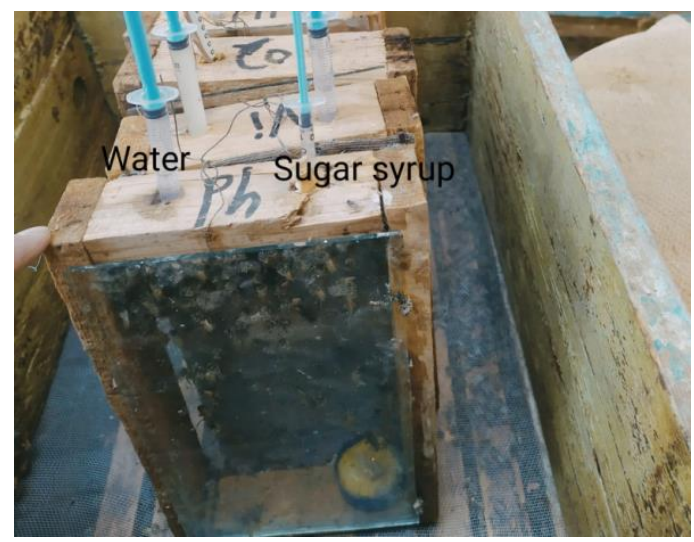

Fig(1): Experimental cages using newly emerged honeybee workers.

The tested cages were divided into 6 groups, three cages in each group. Each of the four pollen types described in Table (1) was introduced to a different group, fifth group fed on mixture from all pollen types at a rate of $25 \%$ of each type, while the sixth group without pollen diet served as control.

Each pollen type was prepared in the form of pollen cake (50\% pollen $+30 \%$ powdered sugar $+20 \%$ honey) and knead it until become homogeneous as described by [28].

Table (1): Classifications of main pollen sources in the study area during 2018-2019 season

\begin{tabular}{|l|l|l|}
\hline Common name & Family name & Scientific name \\
\hline Broad bean & Fabaceae & Vicia faba $\mathrm{L}$. \\
\hline Date palm & Arecaceae & Phoenix dactylifera $\mathrm{L}$. \\
\hline Egyptian clover & Fabaceae & Trifolium alexndrinum $\mathrm{L}$. \\
\hline Maize & Poaceae & Zea mays L. \\
\hline
\end{tabular}

Each cage was provide with one syringe of tap water and other syringe of sugar solution $1: 1(\mathrm{w} / \mathrm{v})$ and a piece of wax comb attached to the top of each cage. In addition, the pollen types 
were introduced to each cage in small plastic feeders. $(1 \mathrm{~cm}$. height and $3 \mathrm{~cm}$. diameter). Each feeder contained an average amount of $5 \mathrm{gm}$. The diets were changed in cages every 3 days. All cages held in darkness in under hive conditions, and reared for up to 18 days [28].

\section{Food consumption:}

Food consumption was calculated as mg/bee/3 days until 18 days old. The tested pollen types was offered to each cage. Equal amounts $(5 \mathrm{~g})$ of each pollen type were weighted and introduced to each cage. Three days later, the net weight of the remaining pollen diet was recorded to calculate the consumed amount and then new diets were provided to cages. This procedure was repeated 6 times with three days interval.

\section{Determination of hypopharyngeal gland development:}

Development of hypopharyngeal glands was determined in honeybee workers of 3, 6, 9, 12 and 15 days old as in Photo 2: (A, B, C, D and E). Five bees per cage were used to assimilate each age from each treatment. The head of the bee was dissected dorsally with scalpel surgical blade, the glands were extracted from the head capsule with forceps and placed into a droplet of physiological solution (sodium chloride $0.85 \%$ ).

The maximum length and width $(\mathrm{mm})$ of five acini were measured for each worker under stereomicroscope using a micrometer eyepiece. Stereoscope microscope provided with ocular micrometer lens was used for this purpose. The recorded measurements were modified according to power of ocular and objective lenses used. Acinal surface area was calculated according to [32] formula:

Acinal surface area $=\pi \frac{\mathrm{a} \times \mathrm{b}}{2}$

Where $\mathrm{a}=$ maximum length,

$\mathrm{b}=$ maximum width, $=3.14$.
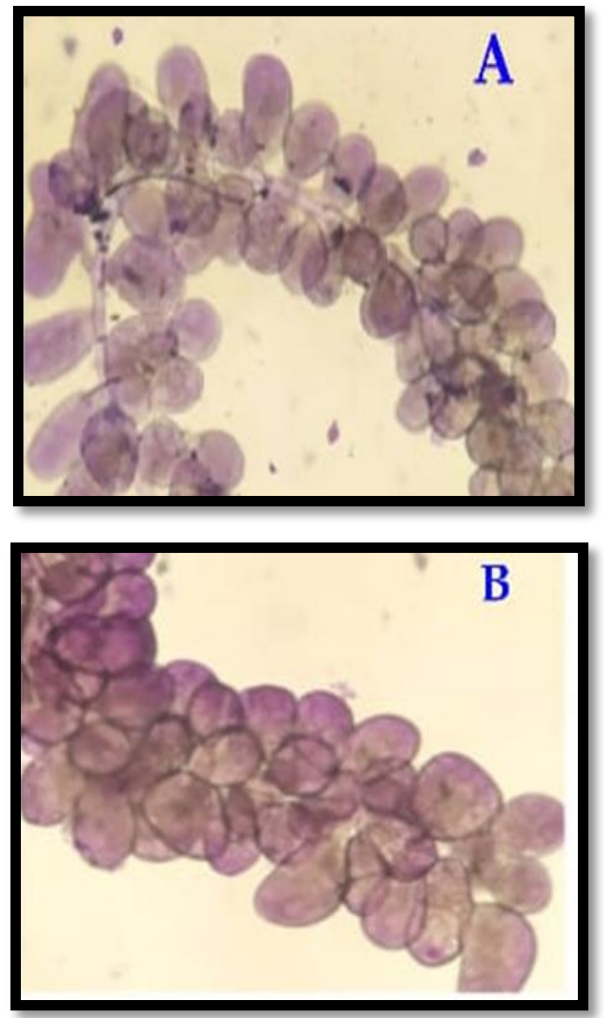
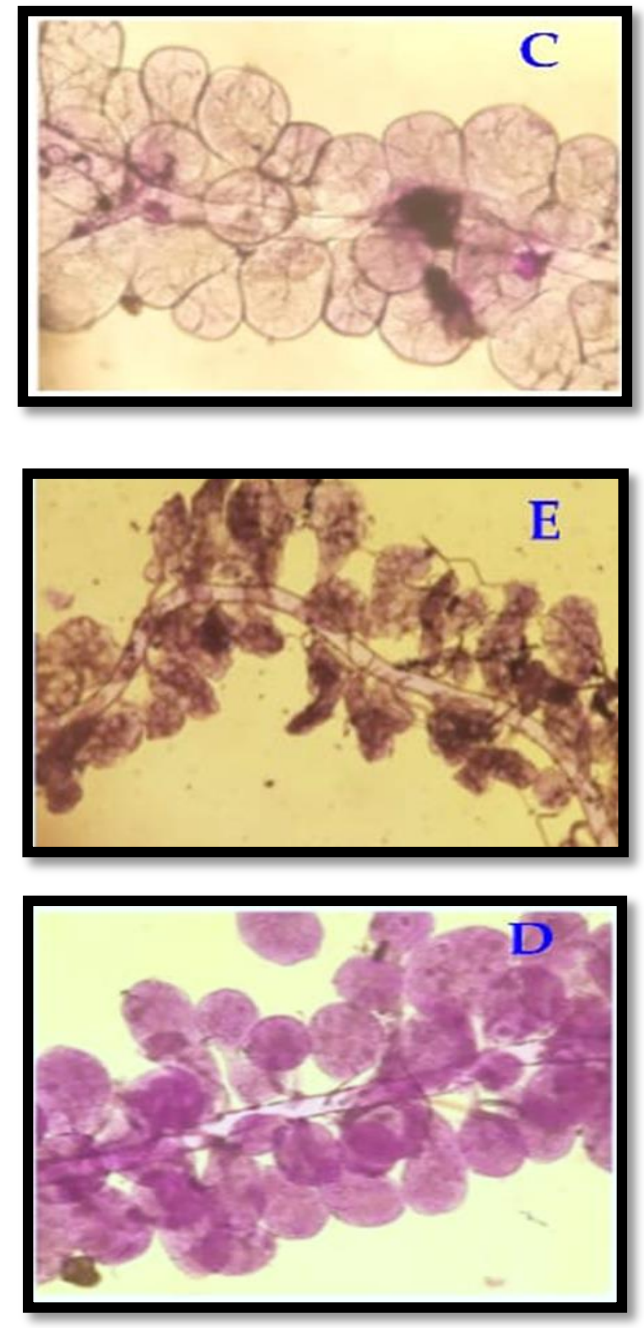

Fig (2): HPG of the nurse bees at A. 3 days, B. 6 days, C. 9 days, D. 12 days and E. 15 days.

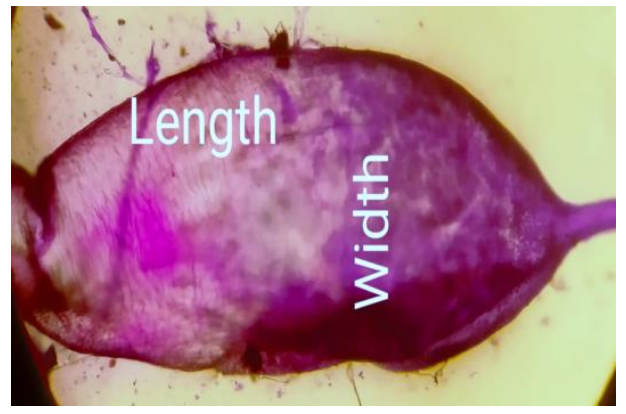

Fig (3): Length and width of AG sac.

\section{Determination of acid gland development:}

The volume of venom sac of acid gland was determined on honeybee workers of 15,18 , and 21 days old. Five bees per cage were used to assimilate each age from each treatment. The sting apparatus of honey bee workers was separated using forceps and placed into a droplet of physiological solution (sodium chloride $0.85 \%$ ) and examined under a binocular microscope .

The development and expressed of the acid gland was evaluated by measuring the volume of the venom sac, because the filling degree of the venom sac depends on the amount of venom secretion by the acid gland [23]. The maximum length and 
width of acid gland sac were measured in $\mathrm{mm}$ for each worker from the treatments under stereomicroscope using a micrometer eyepiece as in Photo 3. Stereoscope microscope provided with ocular micrometer lens was used for this purpose. The recorded measurements were modified according to power of ocular and objective lenses used.

The volume of the acid gland sac was calculated by applying the following formula:

Volume of acid gland sac $=\frac{4}{3} \pi \times\left(\frac{\mathrm{a}+\mathrm{b}}{4}\right)^{3}$

Where $\quad \mathrm{a}=$ maximum length, $\quad \mathrm{b}=$ maximum width, $\quad \pi$ $=3.14$.

\section{Statistical Analysis:}

Data were statistically analyzed using Costat program software [33] with ANOVA and Duncan's test to examine the differences between means and their interactions.

\section{RESULT AND DISCUSSION:}

\section{Chemical analysis of pollen types:}

Data tabulated in Table (2) showed chemical analysis (moisture, total protein, carbohydrate, lipids, ash and crude fiber percentage) of four main types of pollen collected by honey bee colonies in the study area. Maize pollen had the lowest moisture percentage (12.90) in comparison with the other pollen types, while the highest mean was 18.90 in date palm .The highest percentags of total protein were 22.68 and 21.94 determined in Egyptian clover and broad bean pollens, respectively, while the lowest percentages were 16.84 and 19.55 determined in maize and date palm pollen grains, respectively. Maize pollen had the highest value of in carbohydrate percentage of 24.13 which while the lowest percentage was 18.85 in broad bean pollen. Broad bean pollen had the lowest lipids percentage (1.75) in comparison to other pollen types while the highest means (5.44) in date palm. The highest percentage of ash (9.75) were determined in date palm pollen, while the lowest percentage (2.50) was determined in Egyptian clover pollen. The highest percentages of crude fiber were 8.28 and 6.04 in date palm and maize pollens respectively, while the lowest percentages were 5.15 and 5.23 in broad bean and Egyptian clover pollens, respectively.

Table (2): Chemical analysis of different pollen types collected by honey bee colonies.

\begin{tabular}{|l|l|l|l|l|l|l|}
\hline Pollen type & \multicolumn{6}{|c|}{ Percentage of pollen types component. } \\
\cline { 2 - 8 } & Moisture & Protein & Carbohydrate & Lipids & Ash & $\begin{array}{l}\text { Crude } \\
\text { fiber }\end{array}$ \\
\hline Broad bean & 15.90 & 21.94 & 18.85 & 1.75 & 3.75 & 5.15 \\
\hline Date palm & 18.90 & 19.55 & 20.21 & 5.44 & 9.75 & 8.28 \\
\hline $\begin{array}{l}\text { Egyptian } \\
\text { clover }\end{array}$ & 14.00 & 22.68 & 24.02 & 4.88 & 2.50 & 5.23 \\
\hline \begin{tabular}{l} 
Maize \\
\cline { 2 - 7 }
\end{tabular} & 12.90 & 16.84 & 24.13 & 3.31 & 3.00 & 6.04 \\
\hline
\end{tabular}

\section{Food consumption:}

Data tabulated in Table (3) and illustrated in Figure (1) showed clearly that there were significant differences in the mean amounts of daily consumption (mg./bee/3days) of different types of pollen by caged honey bees. The highest consumption of pollen diets was at the age of 6 days old bees in all diets. The consumption of pollen decreased gradually at days 9 of old bees till the end experiment. The lowest consumption recorded was at the age 18 days of old bees. It is obvious that total food consumption through the 18 days was significantly different between types of pollen diets, where the highest food consumption was recorded when the workers were fed on date palm pollen $(75.42 \mathrm{mg}$ ) compared with other pollen mix and clover pollen (71.42 and $71.00 \mathrm{mg}$ ) respectively. While the lowest food consumption percentage was 59.17 and $69 \mathrm{mg}$ from maize pollen and broad bean pollen, respectively.

Table (3): Consumption of different types of pollen by caged honey bees during a period of 18 days.

\begin{tabular}{|c|c|c|c|c|c|c|c|c|}
\hline \multirow{2}{*}{$\begin{array}{l}\begin{array}{l}\text { Name } \\
\text { of } \\
\text { pollen } \\
\text { source }\end{array} \\
\end{array}$} & \multicolumn{6}{|c|}{ Diet consumption (mg/bee/3days) } & \multirow{2}{*}{$\begin{array}{l}\text { Total } \\
\text { consum } \\
\text { ption }\end{array}$} & \multirow{2}{*}{$\begin{array}{l}\text { Gener } \\
\text { al } \\
\text { mean }\end{array}$} \\
\hline & $\begin{array}{c}3 \\
\text { days }\end{array}$ & $\begin{array}{c}6 \\
\text { days }\end{array}$ & $\begin{array}{c}9 \\
\text { days }\end{array}$ & $\begin{array}{c}12 \\
\text { days }\end{array}$ & $\begin{array}{c}15 \\
\text { days }\end{array}$ & $\begin{array}{l}18 \\
\text { days }\end{array}$ & & \\
\hline $\begin{array}{l}\text { Broad } \\
\text { bean }\end{array}$ & 12.25 & 22.50 & 13.92 & 09.75 & 6.75 & 3.83 & 69.00 & $\begin{array}{c}11.50 \\
\mathrm{c}\end{array}$ \\
\hline $\begin{array}{l}\text { Date } \\
\text { palm }\end{array}$ & 12.92 & 25.50 & 14.17 & 11.17 & 7.67 & 4.00 & 75.42 & $\begin{array}{c}12.57 \\
\mathrm{a}\end{array}$ \\
\hline Clover & 12.83 & 24.67 & 13.67 & 10.08 & 6.42 & 3.33 & 71.00 & $\begin{array}{c}11.83 \\
b\end{array}$ \\
\hline Maize & 11.25 & 19.83 & 10.75 & 08.42 & 5.50 & 3.42 & 59.17 & $\begin{array}{c}09.86 \\
\mathrm{~d}\end{array}$ \\
\hline $\begin{array}{l}\text { Pollen } \\
\text { mix }\end{array}$ & 12.00 & 22.75 & 14.08 & 11.00 & 7.67 & 3.92 & 71.42 & $\begin{array}{c}11.90 \\
\mathrm{~b}\end{array}$ \\
\hline $\begin{array}{l}\text { General } \\
\text { mean }\end{array}$ & $\begin{array}{c}12.25 \\
\mathrm{c}\end{array}$ & $\begin{array}{c}23.05 \\
a\end{array}$ & $\begin{array}{c}13.32 \\
b\end{array}$ & $\begin{array}{c}10.08 \\
\mathrm{~d}\end{array}$ & $\begin{array}{c}6.80 \\
\mathrm{e}\end{array}$ & $\begin{array}{c}3.70 \\
\mathrm{f}\end{array}$ & - & - \\
\hline L.S.D & \multicolumn{8}{|c|}{ Age $=0.306$} \\
\hline
\end{tabular}

Means marked by the same letter at the same row or the same column are not significantly different at $\mathrm{P} \leq 0.05$ of probability.

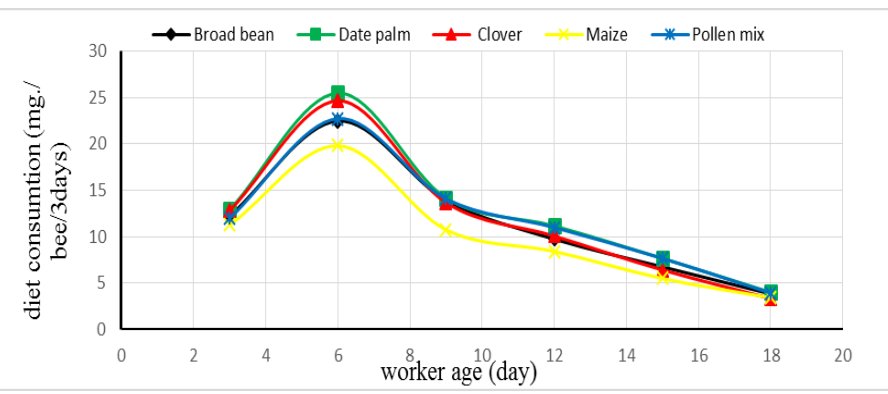

Fig. (3): Consumption of different types of pollen by caged honey bees during a period of 18 days.

The present result was in agreement with [34] and [35] who showed that the the peak of pollen consumption by honeybee workers was recorded at 3-10 days old. This percentage decreased sharply at 12 days old and decreased to low level by time. Similar results were obtained by [36] who said that pollen was consumed by bees until they reached the age of 15-18 days. The diets were not equally consumed in cages, this preference may be due to the quality of the pollen and purity of 
each diet [37]. [38] indicated that fat content of 6-10\% in protein substitutes could increase consumption. There was an evidence that the protein content and amino acid contents may play a role in determination of the amount of food consumed by honey bees [8], this is consistent with the results of current work.

\section{Hypopharyngeal glands developments:}

The development of HPG was evaluated by measuring the average acinal surface area of after the honey bee workers had been fed on different types of pollen.

The data obtained in Table (4) and illustrated in Figure (2) showed that the age of the bees in which the development of the gland could be affected and increased gradually at the 9 daysold. The considering increment in the average acinal surface area of HPG had been obtained during this age, that resembles the highest significant degree of development among the compared treatments. The development of HPG decreased gradually until the age of 15 days old. Workers fed on mixed pollen diet had the best average acinal surface area of HPG $(0.0450 \mathrm{~mm} 2)$ followed by those fed on broad bean pollen and clover pollen with similar degree $(0.0411$ and $0.0401 \mathrm{~mm} 2)$, respectively, then followed by those fed on date palm and maize $(0.0361$ and $0.0340 \mathrm{~mm} 2)$ respectively. Whereas, bees fed sugar solution only (control) had the lowest acinal surface area of HPG $(0.0223 \mathrm{~mm} 2)$ compared with other pollen diets, with statistically significant differences.

Table (4): Effect of feeding caged honeybee workers with different types of pollen on surface area of acinal of hypopharyngeal gland.

\begin{tabular}{|c|c|c|c|c|c|c|}
\hline \multirow{2}{*}{$\begin{array}{l}\text { Name of } \\
\text { pollen } \\
\text { source }\end{array}$} & \multicolumn{5}{|c|}{$\begin{array}{c}\text { Average acinal surface area }\left(\mathrm{mm}^{2}\right) \text { of the } \\
\text { hypopharyngeal gland }\end{array}$} & \multirow{2}{*}{$\begin{array}{c}\text { Gener } \\
\text { al } \\
\text { mean }\end{array}$} \\
\hline & $\begin{array}{l}\text { 3-days } \\
\text { old }\end{array}$ & $\begin{array}{c}\text { 6-days } \\
\text { old }\end{array}$ & $\begin{array}{l}\text { 9-days } \\
\text { old }\end{array}$ & $\begin{array}{c}\text { 12-days } \\
\text { old }\end{array}$ & $\begin{array}{c}\text { 15-days } \\
\text { old }\end{array}$ & \\
\hline $\begin{array}{l}\text { Broad } \\
\text { bean }\end{array}$ & 0.0287 & 0.0457 & 0.0492 & 0.0452 & 0.0368 & $\begin{array}{c}0.0411 \\
b\end{array}$ \\
\hline $\begin{array}{l}\text { Date } \\
\text { palm }\end{array}$ & 0.0262 & 0.0416 & 0.0460 & 0.0406 & 0.0260 & $\begin{array}{c}0.0361 \\
\mathrm{c}\end{array}$ \\
\hline Clover & 0.0277 & 0.0462 & 0.0463 & 0.0445 & 0.0359 & $\begin{array}{c}0.0401 \\
b\end{array}$ \\
\hline Maize & 0.0221 & 0.0377 & 0.0434 & 0.0383 & 0.0287 & $\begin{array}{c}0.0340 \\
\mathrm{~d}\end{array}$ \\
\hline $\begin{array}{l}\text { Pollen } \\
\text { mix }\end{array}$ & 0.0330 & 0.0492 & 0.0548 & 0.0484 & 0.0396 & $\begin{array}{l}0.0450 \\
\mathrm{a}\end{array}$ \\
\hline Control & 0.0149 & 0.0231 & 0.0308 & 0.0244 & 0.0180 & $\begin{array}{c}0.0223 \\
\mathrm{e}\end{array}$ \\
\hline $\begin{array}{l}\text { General } \\
\text { mean }\end{array}$ & $\begin{array}{c}0.0255 \\
\mathrm{~d}\end{array}$ & $\begin{array}{c}0.0406 \\
b\end{array}$ & $\begin{array}{c}0.0451 \\
\mathrm{a}\end{array}$ & $\begin{array}{c}0.0402 \\
\mathrm{~b}\end{array}$ & $\begin{array}{c}0.0309 \\
\mathrm{c}\end{array}$ & - \\
\hline L.S.D & \multicolumn{3}{|c|}{ Age $=0.0016$} & \multicolumn{2}{|c|}{ Feeding $=0.0015$} & \\
\hline
\end{tabular}

Means marked by the same letter at the same row or the same column are not significantly different at $\mathrm{P} \leq 0.05$ of probability.

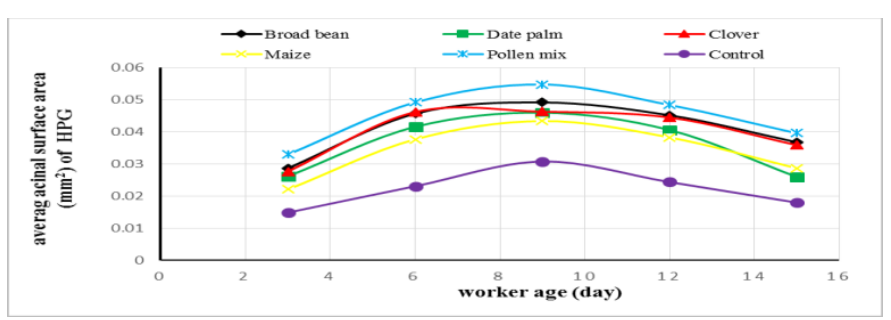

Fig. (2): Effect of feeding honeybee workers with different types of pollen on acinal surface area of hypopharyngeal glands.

Data tabulated in Table (5) showed that the amount of protein intake is may be the main factor in the development of HPG glands, where it was found that there is a correlation sometimes between the amount of protein intake and the increase in the surface area of the lobes of the hypopharyngeal glands, data obtained showed that the amount of total protein intake $(16.10,15.14,14.74,14.46$ and $9.96 \mathrm{mg} / \mathrm{bee} / 18 \mathrm{days})$ were determined in clover pollen, broad bean pollen, date palm pollen, pollen mix and maize, respectively. Also as shown previously in Table (4) workers fed on mixed pollen diet had the best average acinal surface area of HPG followed by those fed on broad bean pollen and clover pollen with similar degree then followed by those fed on date palm and maize respectively. Whereas, bees fed sugar solution only (control) had the lowest acinal surface area of HPG compared with other pollen diets, with statistically significant differences.

Table (5): Effect of feeding pollen source on acinal surface of hypopharyngeal glands.

\begin{tabular}{|l|c|c|c|c|}
\hline $\begin{array}{l}\text { Pollen } \\
\text { source }\end{array}$ & $\begin{array}{c}\text { Total } \\
\text { consumption } \\
\text { (mg/bee/18days) }\end{array}$ & $\begin{array}{c}\text { Percent } \\
\text { protein content } \\
\%\end{array}$ & $\begin{array}{c}\text { Total protein } \\
\text { intake } \\
(\mathbf{m g} / \mathbf{b e e} / 18 \mathrm{da} \\
\mathbf{y s})\end{array}$ & $\begin{array}{c}\text { Acinal } \\
\text { surface area } \\
\left(\mathbf{m m}^{2}\right)\end{array}$ \\
\hline $\begin{array}{l}\text { Broad } \\
\text { bean }\end{array}$ & $69.00 \mathrm{c}$ & 21.94 & 15.14 & $0.0411 \mathrm{~b}$ \\
\hline Date palm & $75.42 \mathrm{a}$ & 19.55 & 14.74 & $0.0361 \mathrm{c}$ \\
\hline Clover & $71.00 \mathrm{~b}$ & 22.68 & 16.10 & $0.0401 \mathrm{~b}$ \\
\hline Maize & $59.17 \mathrm{~d}$ & 16.84 & 9.96 & $0.0340 \mathrm{~d}$ \\
\hline Pollen mix & $71.42 \mathrm{~b}$ & 20.25 & 14.46 & $0.0450 \mathrm{a}$ \\
\hline Control & - & - & - & $0.0223 \mathrm{e}$ \\
\hline
\end{tabular}

Means marked by the same letter at the same column are not significantly different at $\mathrm{P} \leq 0.05$ of probability.

The present results were in agreement with [35] who reported that there was a positive relationship between the pollen consumption and diameter of HPG and protein synthesis during the nursing bees of honeybee workers. Similar results were obtained by [25] which clarified that different diets affected the development of HPG, the acini of HPG attained their maximum size in caged bees at an age of 5 days. Bees fed with mixed pollen had the largest glands acinal area among all test groups of this age. Statistical analysis showed highly significant differences between acinal surface area of HPG in honey bee workers fed on different pollen diets, these differences may be due to the variation in protein content of the pollen diets.

In this concern, [39] and [40] indicated that the hypopharyngeal gland development seemed to be related to the protein content of the pollen diets. The results of our confirm those of [41], [42] and [43] they found that pollen grains had a wide range of physiological effects on honey bee, such as HPG development, which affected by pollen quality.

\section{Determination of acid gland development:}


The development and expressed of acid gland (AG) was evaluated by measuring the volume of the venom sac, after the honey bee workers had been fed on different types of pollen diets. Data obtained in Table (6) and illustrated in Figure (3) showed that the age of bees in which the development of gland could be effect occurred increased gradually at 12 to 18 daysold. The considering increment in average of acid gland sac volume has been obtained at 18 days-old, that resembles the highest significant degree of development among the compared treatments, the pollen different types influenced the volume of $\mathrm{AG}$ sacs in bees. It is clear that the greatest mean volume of AG sacs in bees was observed when bees were fed on broad bean mix pollen and clover diets $(0.6419,0.6291$ and $0.6076 \mathrm{~mm} 3)$ respectively, with statistically no significant differences among the three diets of pollen. followed by those fed on date palm pollen and maize pollen with degree insignificant $(0.5763$ and $0.5565 \mathrm{~mm} 3$ ) respectively, While the bees were fed sugar solution only (control) had the lowest average the volume of AG sacs in bees $(0.3643 \mathrm{~mm} 3)$ compared with other pollen diets, with statistically significant differences.

Table (6): Effect of feeding caged honeybee workers with different types of pollen on the volume of acid gland sac.

\begin{tabular}{|c|c|c|c|c|}
\hline \multirow[t]{2}{*}{$\begin{array}{l}\text { Name of pollen } \\
\text { source }\end{array}$} & \multicolumn{3}{|c|}{$\begin{array}{c}\text { Average volume }\left(\mathrm{mm}^{3}\right) \text { of acid } \\
\text { gland sac }\end{array}$} & \multirow[t]{2}{*}{$\begin{array}{c}\text { General } \\
\text { mean* }\end{array}$} \\
\hline & $\begin{array}{l}\text { 12-days } \\
\text { old }\end{array}$ & 15-days old & $\begin{array}{l}\text { 18-days } \\
\text { old }\end{array}$ & \\
\hline Broad bean & 0.3655 & 0.7147 & 0.8456 & $0.6419 \quad \mathrm{a}$ \\
\hline Date palm & 0.2629 & 0.7074 & 0.7585 & $0.5763 \mathrm{bc}$ \\
\hline Clover & 0.2939 & 0.7287 & 0.8003 & $0.6076 \mathrm{abc}$ \\
\hline Maize & 0.3077 & 0.6367 & 0.7250 & $0.5565 \quad \mathrm{c}$ \\
\hline Pollen mix & 0.2534 & 0.8174 & 0.8165 & $0.6291 \mathrm{ab}$ \\
\hline Control & 0.2541 & 0.4192 & 0.4196 & $0.3643 \quad \mathrm{~d}$ \\
\hline General mean & $0.2896 \mathrm{c}$ & $0.6707 \mathrm{~b}$ & $0.7276 \mathrm{a}$ & - \\
\hline L.S.D & & $=0.0556$ & Feedin & 0393 \\
\hline
\end{tabular}

* Means marked by the same letter at the same row or the same column are not significantly different at $\mathrm{P} \leq 0.05$ of probability.

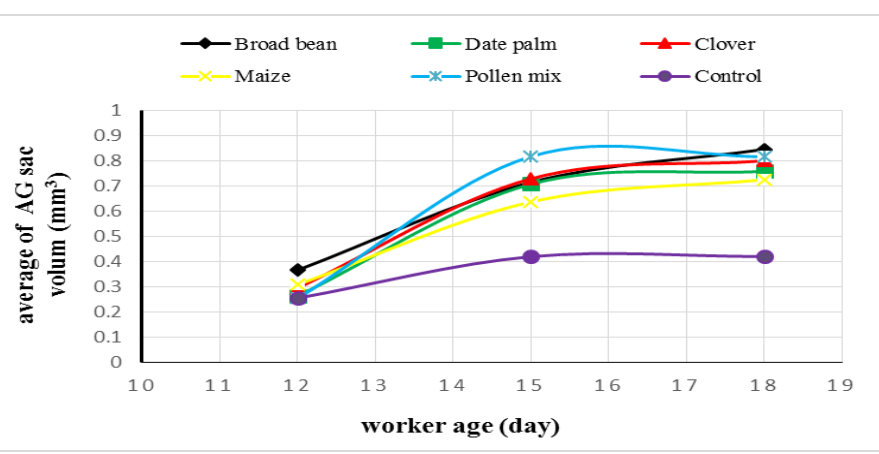

Fig. (3): Effect of feeding caged honeybee workers with different types of pollen on average the volume of acid gland sac.

Regarding the effect of honeybee age on venom gland development, [21] indicated that length of AG sac and width of AG sac was increased at 21-day old than at 18-day old. The width of acidic sac also increased at 21 worker's day old than at 18 worker's day old in control and feeding treatment, this was consistent with the results of current work. [25] obtained similar results, reported that there was the AG sac volumes increased with the age of the bees and did not degenerate like the HPG. In this regard, [23] indicated that the AG sac volumes continued to increase with age because bees prepare themselves for guarding tasks, during which they need venom for colony defense. Regarding the effect of different diets on the development of the acid gland, [21] showed that the feeding honey bee colonies on pollen substitute significantly increases the parameters of honey bee worker's AG sac (length of acid sac and width of acid sac) compared with control honey bee colonies (only fed on sugar syrup). These differences may be due to protein content of the diets.

\section{CONCLUSIONS:}

It was concluded that different pollen types provide different nutritional benefits. Thus, the honey bee workers were impacted by using different pollen loads types. Date palm pollen had better results than other in food consumption rate. Feeding honey bees on mixture pollen diet and broad bean pollen diet resulted had better results than other in development of HPG and AG. Feeding honey bees on sugar solution only resulted insignificant reductions of all tested variables.

Therefore, this study recommends placing pollen traps at times when pollen is available and presenting them in the form of pies at a time of scarcity, which stimulates the development of hypopharyngeal glands and thus increases brood activity and colony in general.

\section{REFERENCES}

[1] Roulston, T. H. and Cane, J. H. (2000). Pollen nutritional content and digestibility for animals. Plant Systematics and Evolution, 222(1/4):187-209.

[2] Keller, I.; Fluri, P. and Imdorf, A. (2005). Pollen nutrition and colony development in honeybees: part II. Bee Wld., 86(2): 27-34.

[3] Barker, R. J. and Lehner, Y. (1974). Acceptance and sustenance value of naturally occurring sugars fed to newly emerged adult workers of honey bees (Apis mellifera L.). J. Experimental Zoology, 187(2): 277-285.

[4] Pernal, S F. and Currie, R. W. (2000). Pollen quality of fresh and 1-year-old single pollen diets for worker honey bees (Apis mellifera L.). Apidologie, 31(3): 387-409.

[5] Herbert, E. W. (2000). Honey bee nutrition. In J. M. Graham (Ed.), The hive and the honeybee. Dadant and Sons, Hamilton, Illinois, pp. 197-233.

[6] Radev, Z. (2018). Variety in protein content of pollen from 50 plants from Bulgaria. Bee Wld., 95(3): 81-83.

[7] Herbert, E.W.; Shimanuki, H. and Caron, D.M. (1977). Optimum protein levels required by honeybees (Hymenoptera, Apidae) to initiate and maintain brood rearing. Apidologie, 8(2): 141-146.

[8] Nicolson, S. W. (2011). Bee food: The chemistry and nutritional value of nectar, pollen and mixtures of the two. Review article. African Zoology, 46(2): 197-204.

[9] Brodschneider, R. and Crailsheim, K. (2010). Nutrition and health in honeybees. Apidologie, 41 (3): 278-294.

[10] Abdel-Rahman, M. F. and Moustafa, A. M. (2012). An estimate of honeybee colony losses and their perceived reasons during two years case study in Qena and Luxor Governorates, Upper Egypt. Assiut Journal of Agriculture Science, 43: 164-178.

[11] DeGrandi-Hoffman, G.; Wardell, G.; Ahumada-Segura, F.; Rinderer, $\quad$ T.; $\quad$ Danka, $\quad$ R. 
Pettis, J. (2008). Comparisons of pollen substitute diets for honey bee: consumption rates by colonies and effects on brood and adult population. J. Apic. Res., 47(4): 265- 270.

[12] Schmickl, T. and Crailsheim, K. (2003). Collective and individual nursing investment in the queen and in young and old honeybee larvae during foraging and non-foraging periods. Insectes Soc., 50: 174 - 184.

[13] Crailsheim, K. (1990). The protein balance of the honey bee worker. Apidologie, 21(5): 417-429.

[14] Dietz, A. (1979). Nutrition of the adult honey bee. (ed) Hive and the honey bee, Dadant \& Sons; Hamilton. IL, 125-156.

[15] Deseyn, J. and Billen, J. (2005). Age-dependent morphology and ultrastructure of the hypopharyngeal gland of Apis mellifera workers (Hymenoptera, Apidae). Apidologie, 36 (1): 49-57.

[16] Silva de Moraes, R. L. and Bowen, I. D. (2000). Modes of cell death in the hypopharyngeal gland of the honey bee (Apis mellifera L). Cell Biology Inter., 24(10): 737-743.

[17] Huang, Z. Y. and Otis, G. W. (1989). Factors determining hypopharyngeal gland activity of worker honey bees (Apis mellifera L.). Insect. Soc., 36: 264-276.

[18] Corby-Harris, V.; Meador, C.A.; Snyder, L.A.; Walton, A. and Anderson, K.E. (2015). Transcriptional, translational, and physiological signatures of undernourished honey bees (Apis mellifera) suggest a role for hormonal factors in hypopharyngeal gland degradation. J. Insect Physiol., 85: 65-75

[19] Standifer, L.; McCaughey, W.; Todd, F. and Kemmerer, A. (1960). Relative availability of various proteins to the honey bee. Ann. Entomol. Soc. Am., 53(5): 618-625

[20] Malone, L.A.; Todd, J.H.; Burgess, E.P.J. and Christeller, J.T. (2004). Development of hypopharyngeal glands in adult honey bees fed with a Bt toxin, a biotin-binding protein and a protease inhibitor. Apidologie, 35(6): 655-664.

[21] Nowar, E. E. (2016). Venom glands parameters, venom production and composition of honeybee Apis mellifera L. affected by substitute feeding. Middle East J. Agric. Res., 5(4): 596-603

[22] Roat, T. C.; Nocelli, R. C. and Cruz-Landim, C. D. (2006). Ultrastructural modifications in the venom glands of workers of Apis mellifera L. (Hymenoptera: Apidae) promoted by topical application of juvenile hormone. Neotrop. Entomol., 35(4): 469-476.

[23] Nenchev, P. (2003). Seasonal changes in the venom gland of the honey bee Apis mellifera L. in Bulgaria. Zhivotnovdni Nauki, 40 (5): 87-88.

[24] Snodgrass, R.E. (1984). Anatomy of the honey bee. Cornell University Press, Ithaca, 74-83.

[25] Omar, E.; Abd-Ella, A. A.; Khodairy, M. M.; Crailsheim, K. and Brodschneider, R. (2017). Influence of different pollen diets on the development of hypopharyngeal glands and size of acid gland sacs in caged honey bees (Apis mellifera). Apidologie, 48(4): 425-436.

[26] Dimou, M. and Thrasyvoulou, A. (2007). A comparison of three methods for assessing the relative abundance of pollen resources collected by honeybee colonies. J. Apic. Res., 46(3): 143-147.

[27] Kirk, W.D.J. (1994). Recording the color of pollen loads. Bee Wld., 75(4):169-180.

[28] Williams, G.R.; Alaux, C.; Costa, C. and Doublet, V. (2013).

Standard methods for maintaining adult Apis mellifera in cages under in vitro laboratory conditions. J. Apic. Res., 52(1):1-35

[29] Bell, R.R.; Thornber, E.J.; Seet, J.L.; Groves, M.T.; Nerissa, P. and Bell, D.T. (1983). Composition and protein quality of honey bee collected pollen of Eucalyptus marginata and Eucalyptus calophylla. J. Nut., 113(12): 2479- 2484.

[30] A.O.A.C. (2000). Association of Official Analytical Chemists. Official Methods of Analysis 17 th Ed. A.O.A.C. International Washington D.C, USA.

[31] Roulston, T. H.; Cane, J. H. and Buchmann, S. L. (2000). What governs protein content of pollen: pollinator preferences, pollen pistil interaction, or phylogeny?. Ecological Monographs., 70(4): 617643.

[32] Maurizio, A. (1954). Pollen nutrition and vital processes in the honey bee. Landw. Jb. Schweiz, 68: 115-182.
[33] Mead, R.; Curnow, R. N. and Herted, A. M. (1993). Statistical in agriculture and experimental Biology. Chapman and Hall, London. 2nd Ed., Chapman \& Hall Ltd., London, 335 pp.

[34] Pain, J. (1961). Sur quelques facteures alimentaires, accelerateurs du developmental des oeuf dans les ovaries des ouvrieres d' beill (Apis mellifera L.). Insectes Sociaux, 8: 31-93.

[35] Hrassnigg, N. and Crailsheim, K. (1998). The influence of brood on the pollen consumption of worker bees (Apis mellifera L.). J. Insect Physiol., 44: 393-404.

[36] Zherebkin, M. V. (1965). Digestion in bees from weak and strong colonies. Pchelovodstvo, 42: 25-27.

[37] Schmidt, J.O. (1985). Phagostimulants in pollen. J. Apic. Res., 24(2): 107-114.

[38] Stace, P. and Hayter, J. (1994). Palatability of five protein feed stuffs by honeybees (Apis mellifera L.). Australian Beekeeper, 96 (1): 23 - 25.

[39] Darhous, S. A. A. (1990). Effect of artificial feeding on honey bee, Apis mellifera L. M. Sc. Thesis, Fac. Agric., Zaguzig Univ., Egypt., 150 pp.

[40] Atallah, M. A.; Mofttah, E. A.; Eshbah H. M.; Mohamed, A. A. and Eyssa, N. A. (1995). Effect of protein feeding on the development of hypopharyngeal gland of two races of honeybee and the chemical composition of royal jelly. $6^{\text {th }}$ Nat. Conf. of Pest. \& Dis. Veg. \& Fruits in Egypt, 88-100.

[41] Di Pasquale, G.; Salignon, M.; Le Conte, Y.; Belzunces, L. P.; Decourtye, A.; Kretzschmar, A. and Alaux, C. (2013). Influence of pollen nutrition on honey bee health: do pollen quality and diversity matter?. PloS one, 8(8): e72016.

[42] Amro, A.; Omar, M. and AL-Ghamdi, A. (2015). Physiological effects of selected pollen loads types on honey bee workers (Apis mellifera L.). J. Inter. Acad. Res., 3(7): 104-116.

[43] Ahmed, Z. H.; Tawfik, A. I.; Abdel-Rahman, M. F. and Moustafa, A. M. (2020). Nutritional value and physiological effects of some proteinaceous diets on honey bee workers (Apis mellifera L.). Bee Wld., 97(1): 26-31. 